\title{
FINANCIAL CONVERGENCE AT THE WORLD FINANCIAL MARKET: PENSION FUNDS AND INSURANCE ENTITIES PROSPECTS: CASE OF CHINA, EU, USA
}

\author{
Natalia KUZNETSOVA®, Zhanna PISARENKO®* \\ Risk Management and Insurance Department, Faculty of Economics St. Petersburg State University \\ Universitetskaja Naberezhnaja 7/9, 199034, St. Petersburg, Russian Federation \\ *E-mail: z.pisarenko@spbu.ru
}

\begin{abstract}
Purpose - to find whether large international institutional investors regardless of their country of origin due to the influence of external factors demonstrate convergence on some basic performance indicators.

Research methodology is based on testing the set of selected entities for sigma convergence. The paper presents an empirical analysis of financial convergence for autonomous pension funds and insurance corporations of China, the EU and the USA.

Findings - the insurance segment of the world financial market is more converged; however, current pension reforms in many countries is supposed to and must unify the requirements for both market segments and will lead to even greater convergence between pension funds and insurance corporations.

Practical implications - results of the research are another step towards understanding the convergence processes, which are an objective trajectory for the development of the modern global financial market.

Originality/Value - found intersegment convergence of pension and insurance entities, which needs further research.
\end{abstract}

Keywords: financial convergence, institutional investors, pension funds, insurance corporations, reserves, assets.

JEL Classification: G23, G28.

Conference topic: Contemporary Financial Management.

\section{Introduction}

Non-bank financial intermediaries such as insurance corporations and pension funds have significantly increased their influence on the global financial market in the last 10-15 years (Willis Towers Watson, 2018). Guided by long-term policy, they act as strategic investors, stabilizing the financial system of developed countries and accelerating the formation of stock markets in transition economies. According to the International Organization for Economic Cooperation and Development (OECD, 2015), the total volume of pension funds and insurance corporations' assets amounted to more than $\$ 56.6$ trillion in 2015 , while $85 \%$ of the assets were concentrated in the five largest economies of the world (USA, China, Germany, Japan, and the United Kingdom) (Statistics Times, 2018).

In the upcoming decades, the pension and insurance segments of the global financial market will become one of the most dynamically developing and increasingly attractive for investors. It will lead to increased competition among entities (Barro \& Sala-i-Martin, 1998) operating not only within the separate pension and insurance sectors of the global financial market but also to an intersectoral competition of pension and insurance segments.

This is primarily due to the transfer by the state of poverty risk in old age management from the public to the individual level (pension reforms are implemented in almost all countries of the world) (Belozyorov \& Pisarenko, 2015; Pisarenko, Kuznetsova, \& Chernova, 2017). Pension reforms are forming a great pool of individual investors with the increasing need for long-term insurance pension programs related to public participation in voluntary retirement insurance and long-term life insurance. This trend is also evident in the circumstances of increasing life expectancy and lower fertility rate.

When operating on the global market, institutes from different sectors of the financial market are seeking competitive position and reducing risks of their own activities. It is necessary for them to find such competitive mechanisms that would take into account not only the specifics but also the similarity and proximity of their operating landscape, for example, customer base, sales markets, similar services provided, etc. (Fein, 2007). 
Such a mechanism turn out to be financial convergence ${ }^{1}$, a distinctive feature of which is the impact on the simultaneous enhance the competitiveness of the entities from different sectors of the financial market.

The phenomenon of financial convergence in many recurrent scientific studies has been associated with a mechanism unification of the financial system across different countries and regions of the world economy. This is the subject of many publications, which analyze different aspects of this phenomenon. At the same time, there is an active debate on both the convergence itself and the emerging processes of regional divergence. Among them are Gupta and Wang (2015); Hristov and Rozenov (2009); Estrada, Park, and Ramayandi, (2012); Convergence and industrial policy in finance (2015); European Commission (2018); Mulder, de Groot, and Kurniawan (2019).

We study the convergence hypothesis from a new approach: convergence processes across institutions of financial markets (insurance companies and pension funds). Convergence of policies and institutions across different segments of financial markets has been a recurrent topic within researchers. This approach is due to the fact that the financial market is a set of interrelated and at the same time relatively separate sectors - banking, insurance, pension, investment, etc. The Relationship of the financial market sectors is manifested in the fact that the functioning of each of them is associated with the activities of other sectors of the financial market. For example, the insurance sector cannot exist without interaction with banking, investment, etc.

New challenges of the XXI century force financial institutions to revise their business processes and product strategies. They form new value chains for consumers. High-tech financial companies entering the financial market make the most of completely new technologies. The competition is carried out in the conditions of the global market and the availability of information for the benefit of the development of information and communication networks and the Internet, mobile applications, etc., when it is possible to find quickly necessary information, compare offers and prices.

For example, In China, online insurance companies carry out insurance sales via the Internet without physical office. The Chinese insurance market regulator allowed the registration of such insurance companies at the end of 2016. Only during the fourth quarter of 2016, CIRC issued four on-line insurance licenses. In addition, the increase in competition in the insurance sector of the financial market is due to specialized online platforms included in the world's largest ecosystems such as Alipay and Taobao of Alibaba group, JD.com and others (China InsurTech Industry Report, 2017).

Thus, the struggle for its own survival, for its consumer, for a place within its financial sector leads to increased competition between the institutions - providers of different financial products within a particular sector. Institutions from different sectors of the financial market are beginning to use similar methods of work, promotion of services, use the same customers, etc. Increased competition within institutes in financial sectors leads to the intersectoral competition.

For the insurance and pension segments of the financial market, the similarity of the activities of the subjects of these sectors describe the following possible types of commonality: product, regulatory, client, technological, sales (Chernova, Pisarenko, \& Kuznetsova, 2018).

This consideration allows us to put forward the following hypothesis: insurance corporations and pension funds, being large international institutional investors regardless their country of origin due to the influence of external factors, should demonstrate convergence in some basic indicators of activity.

\section{Methods of analysis and data for research}

As shown in the studies (Baele, Ferrando, Hoerdahl, Krylova, \& Monnet, 2004; Phillips \& Sul, 2007; Belozyorov \& Pisarenko, 2014) investigating applied aspects of financial market convergence hypothesis it is reasonable to use the sigma convergence technique to measure its impact. The presence and dynamics of the sigma-convergence indicator prove a decrease/increase in the variance (time variation) of the development indicators of economic entities in the sample.

We use a two-step algorithm to prove the $\sigma$-convergence hypothesis in the activities of pension and insurance institutions of the world financial market.

Stage 1. Financial Ratio Analysis. This technique is the most accessible and common way, both internal and external analysis of companies' activities. This type of analysis has both advantages and disadvantages. The undoubted advantage is that financial ratios are relative indicators allow comparing different companies in size.

For the calculation of financial ratios, we formed a Panel Data. D was obtained from official sites of insurance corporations and pension funds. As a tool of calculation has been applied integrated software MS Excel. As a result of the first stage of calculations, we obtained the values of the financial coefficient.

\footnotetext{
${ }^{1}$ Financial convergence - the interpenetration in the activities of the previously competing entities from different segments of the financial market, based on their interrelation and a certain similarity. The process leads to a simultaneous increase in the competitiveness of both participants (Pisarenko, Zh. V., \& Chernova, G. V. (2015). Finansovaya konvergentsiya kak mekhanizm povysheniya konkurentosposobnosti subektov finansovogo rynka. Finansy i kredit, 46(670), 10-23). Van der Berghe, L., \& Verweire, K. (2000). Convergence in the financial services industry. In Geneva Papers on Risk and Insurance - Issues and Practice (Vol. 25(2)).
} 
Financial ratios meet the requirements of a) universality, that is, the possibility of its application to all the companies under consideration; b) the possibility of calculating according to the General pattern (rule); C) availability, that is, the availability of data for analysis in the public reporting of the company.

Stage 2

The $\sigma$-convergence calculation based on financial ratios calculated at the first stage. To prove the existence or absence of convergence between insurance companies and pension funds, we used the following financial ratio. $\sigma$ convergence - a decrease of dispersion for basic indicators of activity over time.

To test the hypothesis, we use the formula the most reasonable method is to calculate the indicators of variation, which, unlike the indicators of variance or standard deviation, will not depend on the scale of the company in question.

The economic interpretation of the indicator is to minimize the values of this coefficient since the value of the standard deviation shows the variation of values in the presented set with the average value of the sample under the study. A smaller value shows that the values in the sample are more closely grouped around the mean value and the results of the market entities are evener.

The choice of regions and countries for this study (The USA, The EU and China) is predetermined by their role in the global financial market. American and European financial markets are world leaders. China in 2014 for the first time surpassed Japan in terms of aggregate financial assets (Global Wealth Report, 2015), while the assets of Chinese pension funds and insurance companies grew at a maximum rate compared to the other two most important financial instruments: bank deposits and securities.

Pension reforms are being carried out in all selected regions, which demonstrate a tendency to shift the risk management of poverty in old age from public to individual level. We selected for the analysis 14 US pension funds

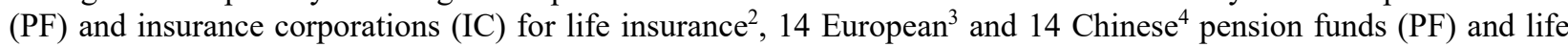
insurance (IC) for life insurance. Total 21 insurance corporations and 21 pension funds were included in the sample. We analyzed the primary information obtained from the annual financial reports of the studied PF and IC for the period 2011-2015, which is presented on the official websites of the companies. Selection criteria - the availability of reporting in the public domain. Selected pension funds and insurance corporations are included in the Top Pension Fund and Insurance Corporations 2015. The time limitation is 2012-2015.

We decided to calculate sigma convergence for the ratio of reserves to assets. The reserves of the IC and PF have a dual nature. Insurance reserves are reflected in the liabilities side of the balance sheet of the insurance organization and, from the accounting point of view, are liabilities, the reserves are not the insurer's income and are temporary free special circulating insurance funds. For the insurer, they are in need to make insurance payments on the current obligations of the insurance company.

Pension funds also form reserves. PF reserves (also called technical reserves) are created for the fund to fulfil its pension obligations (pension payments to customers). Reserves are provided from receipts to clients' pension accounts. Both for insurance and pension reserves, a strict regulatory regime has been established: they can only be used to pay insurance indemnities and the sum insured, indexation of pension accounts, unconditional payments to customers. The reserves are subject to mandatory investment in strict accordance with the requirements of the country's insurance supervisory authorities. Assets covering reserves should satisfy the criterion of diversification, repayment, profitability and liquidity.

\section{Key findings}

In 2015, the US life insurance company, MetLife (608.35 billion US dollars) followed by Prudential Financial (551.62 billion US dollars) and Manulife Financial (272.11 billion US dollars) was the leader in terms of assets in the US market. American corporations in 2014 became absolute leaders also in terms of the written insurance premium, which in the US amounted to 528.22 billion dollars. Chinese companies collected only 177 billion dollars. At the same time, the Asian region became the leader in the growth rate of the assets of institutional investors represented by the PF and IC in the years 2014-2015 (16.6\%). The main driver of growth was the Chinese Financial market, where the growth rate was more than $27 \%$.

Along with the active process of investing in the economy, the liabilities of institutional investors play a significant role as an important component of household welfare. They account for more than $30 \%$ of household savings. Such indicators are comparable only with deposits, i.e. PF and IC actively compete with banks for the households' savings.

\footnotetext{
${ }^{2}$ Pension Funds and Insurance corporations: Federal Retirement Thrift, California Public Employees' Retirement Fund, California State Teachers, New York State Common Retirement Fund, New York City Employees' Retirement System, Florida Retirement System, Teacher Retirement System of Texas; MetLife, Northwestern Mutual, New York Life, Prudential Financial, Lincoln National Corporation, MassMutual, Transamerica.

${ }^{3}$ Insurance corporations (Swiss Life Group, Aviva, Aegon, Zurich Insurance Group, Mapfre, Generali Group) and Pension funds (Industries Pension, BP, Novartis Pension Funds, Keva, Migros-Genossenschafts-Bund).

${ }^{4}$ China Life Insurance, Ping An life insurance company of China, New China Life insurance company, China Pacific insurance, PICC Life insurance company, Taikang Life insurance, Taiping Life insurance, AnBang Life insurance, Funde Sino Life insurance, China Post Life insurance; China Life Pension, Ping An Pension, Taiping Pension, Changjiang Pension (China Pacific).
} 
Life insurance contracts and pension programs are special schemes for long-term savings of the population, and according to the SNA (System of National Accounts, 2008) ${ }^{5}$, insurance premiums paid by households to pension funds and insurance corporations are considered as "savings used to purchase a financial asset".

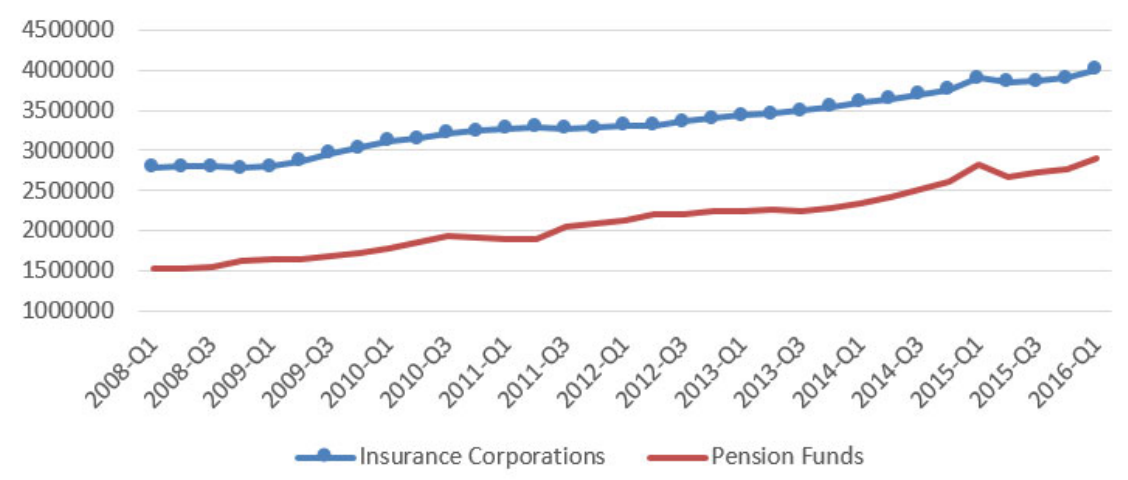

Figure 1. Dynamics of Reserves of life insurance corporations and pension funds (household savings), euro, 2008-2016 (source: compiled by the authors http://sdw.ecb.europa.eu/browse.do?node=9484304)

One can see from Figure 1 that despite the crisis the dynamics of life insurance companies and pension funds reserves size and its growth rate remains positive. Over the fourth quarter of 2015, the total insurance reserves, which are the main source of IC and PF liabilities, increased from 7.52 billion euros to 7.58 billion euros.

So far, insurers are significantly ahead of pension funds, but over the past 15 years, the importance of pension funds in the economies of the world has increased significantly. For example, US PF asset size in 2015 reached $17.4 \%$ of the country's GDP, whereas in 2001 this figure was only $8.9 \%$. In Chile, where there is no state pension system at all, autonomous PF assets reach almost 70\% of GDP. In European countries such as Slovakia, the Czech Republic, and Estonia, the asset size of autonomous pension funds have grown from almost zero to almost $10 \%$ of GDP, which indicates the active development of non-state pension provision.

According to the data of those countries from which we were able to get data from open sources, one can see that the state is reconsidering its attitude towards poverty risk management in old age and partially shifts the concern for well-being at the retirement age to the retiree. This trend is demonstrated by the increasing role of personal pension plans both in the developed and emerging markets economies (Figure 2).

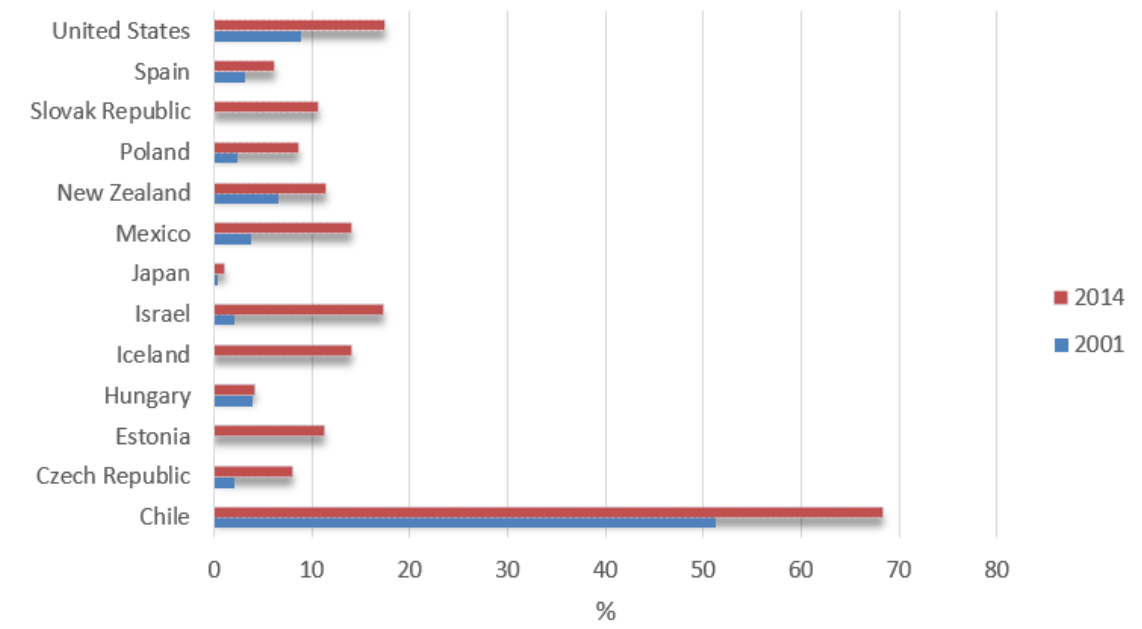

Figure 2. Asset size of autonomous pension funds in selected countries, as a share of GDP, $\%$ (source: compiled by the authors according to http://sdw.ecb.europa.eu/reports.do?node=1000003538)

The structure of the state pension systems is also changing: a significant part of pension plans are financed through autonomous pension funds, pension insurance contracts, and other assets managed by banks and investment companies. They can be financed by corporate pension plans or independently by individuals (personal pension plans).

The total assets of the IC and PF in the Eurozone increased from 9.02 to 9.13 billion euros in the fourth quarter of 2015 despite the crisis. In 2015, the share of assets of pension funds in total assets increased by $1 \%$ and amounted

${ }^{5}$ Official translation of SNA https://unstats.un.org/unsd/nationalaccount/docs/SNA2008Russian.pdf 
to 2.2 billion euros, insurers reduced their share in total assets to $76 \%$, which indicates the increasing importance of pension schemes.

Note that the share of reserves in assets characterizes the attitude of each company to take risks for insurance portfolios on equity, which is of particular importance in modern conditions, so to calculate sigma convergence we use the coefficient: Technical Reserves (TR) to Assets

This indicator is calculated by the formula:

\section{Share of TR in assets $=$ Reserves $/$ Assets .}

The higher the numerical value of the coefficient and its growth in dynamics, the better is the financial stability of the insurer and the pension fund in terms of insurance protection provision. For the purposes of our study, we calculated (in the first turn) the value of the ratio of reserves to assets (2) for each company in our sample for 20112015 period, and then we calculated sigma convergence separately for:

1) insurance corporations (Figure 3),

2) pension funds (Figure 4).

Finally, the whole sample was tested for the presence of convergence.

The dynamics of sigma convergence of insurers is shown in Figure 5.

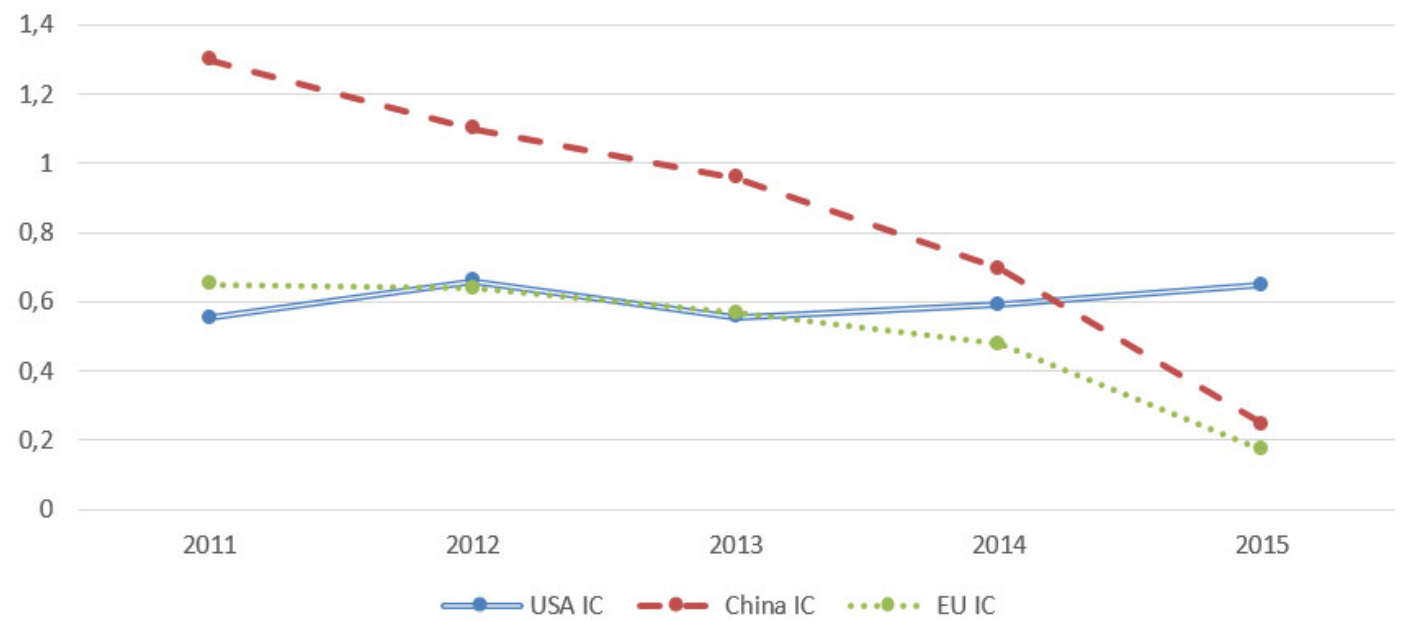

Figure 3. Estimation of sigma convergence parameters for insurance corporations of the USA, China, EU for 2001-2015 period (the ratio of reserves to assets)

In general, convergence is clearly observed in the dynamics of this indicator at the Chinese and European markets. The American insurance market shows a slight divergence. The hypothesis is partially confirmed. The most converged, that is, the most uniform in terms of the dispersion of insurance corporations' reserves/assets is the EU insurance market, which indicates the commitment of European companies to comply not only with the required reserve requirements, but also to follow a conservative strategy for taking high risks.

In the study of the sigma convergence of pension funds of the United States, China and the EU, we recorded a tendency towards convergence (rapprochement) since 2011, and this tendency was most clearly manifested in 2014-2015, that confirms our hypothesis.

Convergence in activities of pension funds in the financial markets of different regions could be explained by similar strategies to investment risk reduction. First of all, it is the avoidance of pension fund insolvency occurred by the time of the client's pension payment start. It depends presumably on the applied scheme of pension payment (DB or DC). In the periods of strong turbulence and low-interest rates in the global financial market financial institution couldn't promise a client certain payment fixed in the contract in the long run so far it may depend on a number of external factors. Therefore, the majority of autonomous pension funds now implement defined contribution programs (defined benefits) transferring investment risks to the client.

One should note that data for the pension segment of China's financial market was obtained only beginning from 2014 - the start of pension reform, which involves the development of non-state pension coverage (see Figure 4).

At the last stage, we analyze the presence of convergence between pension and insurance segments of the US, EU and China financial markets (Figure 5). 
Kuznetsova, N.; Pisarenko, Zh. 2019. Financial convergence at the world financial market: pension funds and insurance entities prospects: case of China, the EU, the USA

2,5

1,5

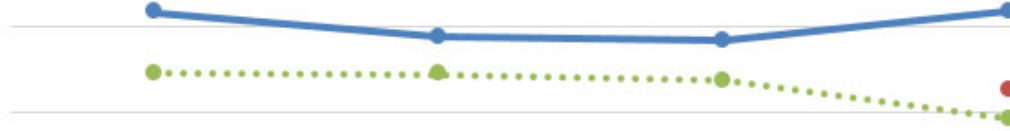

(1)

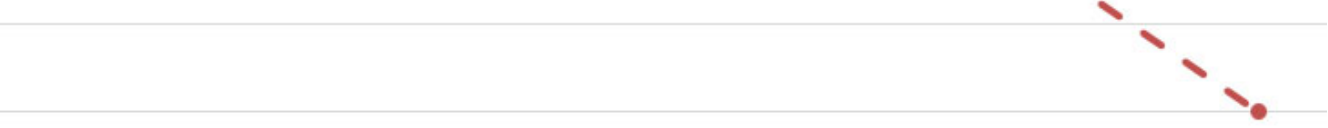

0

2012

2013

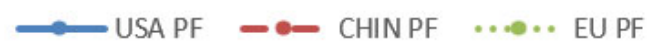

Figure 4. Estimation of the sigma-convergence parameters of the US, China, EU pension funds for the 2011-2015 period (the ratio of reserves to assets)

2,5

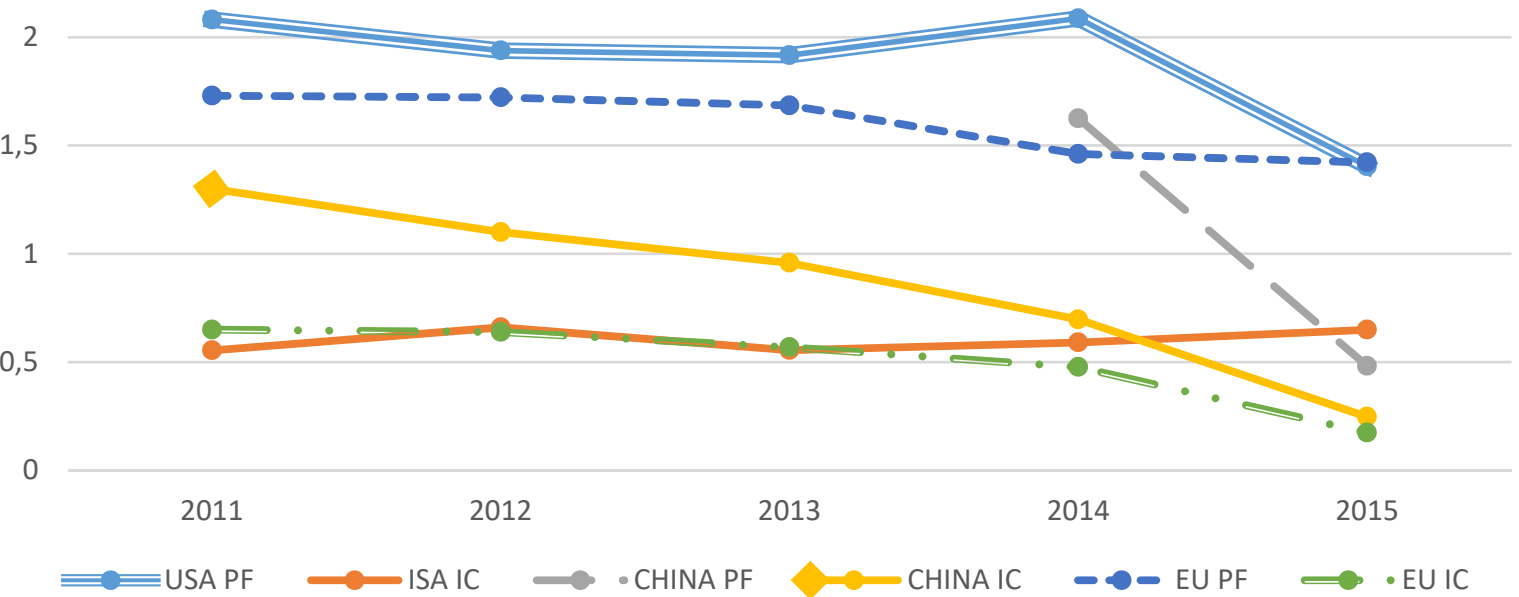

Figure 5. Sigma-convergence of insurance corporations and pension funds parameters estimation in the USA, China, EU for the 2001-2015 period (the ratio of reserves to assets)

Analyzing the presence of convergence between the pension and insurance markets in terms of reserves/assets ratio, it should be noted that since 2014 one observes an obvious process of insurance and pension markets convergence. A small divergence is demonstrated only by the American insurance market. The hypothesis is confirmed.

\section{Conclusions}

1. While examining the activities of the US, China and the EU pension funds (2012-2015) in terms of reserves/assets ratio, we recorded a tendency towards convergence. The hypothesis is proved. One of the factors behind this tendency was the process of transforming pension fund programs based on defined payments (DB) into programs based on certain contributions (DC). De-risking strategies and investment risk reduction strategies are common for PF nowadays. Regulators, in turn, carry out pension reforms which also transfer risks of poverty in old age from public to the individual level.

2. Convergence in the insurance markets is more pronounced, as insurance portfolios of life insurance companies are more optimized and depend not only on the company's segment but also on the structure of insurance payments for each type of insurance, forcing the company to revise the insurance portfolio in favour of less risky segments of the life insurance market.

3. Intersegment convergence also shows a tendency towards convergence of the performance reflected in pension fund's and the insurance company's indicators in the United States, Europe and China. The hypothesis is proved. This trend is most pronounced in China, which indicates the formation of the national insurance and pension segments of the financial market. Chinese Government is implementing existing international experience. The latter is actually 
confirmed by the data of the Chinese regulator itself. Given the global significance of the Chinese economy, this trend should be studied more deeply.

4. The results obtained can be another step towards understanding the convergence processes, which are an objective trajectory for the development of the modern global financial market. According to the calculations, the most uniform and converged segments of the financial markets are insurance markets, compared to the pension markets which are less converged.

5. Pension reforms carried out by all the countries and regions under consideration seem to cause even greater convergence between insurance and pension markets, since the current trend of transferring risk of poverty in old age from public to the individual level implies further development of pension and insurance programs that provide reasonable and fair income from the onset of retirement age. This increases the competition between the entities of different sectors of the financial market, providing essentially similar services.

\section{References}

Baele, L., Ferrando, A., Hoerdahl, P., Krylova, E., \& Monnet, C. (2004). Measuring financial integration in the euro area (Occasional Paper No. 14). European Central Bank. Retrieved from https://papers.ssrn.com/sol3/papers.cfm?abstract_id $=749045$

Barro, R. J., \& Sala-i-Martin, X. (1998) Economic growth. London: The MIT Press.

Belozyorov, S. A., \& Pisarenko, Zh. V. (2014). Empirical analyses for financial convergence of Russian insurance market. Economy of Region, 3, 198-208. https://doi.org/10.17059/2014-3-20

Belozyorov, S. A., \& Pisarenko, Zh. V. (2015). Pension reforms in developed and transitional economies. Ekonomika regiona [Economy of Region], 4, 158-169. https://doi.org/10.17059/2015-4-13

Chernova, G. V., Pisarenko, Zh. V., \& Kuznetsova, N. P. (2018). Finansovaya konvergentsiya kak faktor strukturnoy konkurentsii finansovogo rynka. Finansy, 4, 54-58.

China InsurTech Industry Report. (2017). Retrieved from https://www.oliverwyman.com/content/dam/oliverwyman/global/en/ 2016/oct/OliverWyman_ChinaInsuretech.pdf

Estrada, G., Park, D., \& Ramayandi, A. (2015). Financial development, financial openness, and economic growth. In $A B D$ Economics (Working Paper No. 442). https://doi.org/10.2139/ssrn.2707518

European Commission. (2018). Stability and convergence programmes. Retrieved from https://ec.europa.eu/info/businesseconomy-euro/economic-and-fiscal-policy-coordination/eu-economic-governance-monitoring-prevention-correction/ stability-and-growth-pact/preventive-arm/stability-and-convergence-programmes_en

Fein, M. L. (2007, January). The convergence of financial products and the implications for regulatory convergence. Can we improve policy-making in financial services regulation? American Enterprise Institute. Retrieved from https://www.law. yale.edu/documents/pdf/cbl/Fein_Convergence_Financial.pdf

Global Wealth Report. (2015). Allianz. Retrieved from https://www.allianz.com/v_1444215837000/media/economic_research/ publications/specials/en/AGWR2015_ENG

Gupta, V., \& Wang, J. (2015). Globalization and convergence-divergence debate: strategic perspectives for emerging markets. Journal of Business and Economics Research, 1(2), 69-76. https://doi.org/10.19030/jber.v1i2.2974

Hristov, K., \& Rozenov, R. (2009). Financial convergence in the new EU member states (Working Paper / FINESS 1.2.). DIW Berlin. Retrieved from https://www.researchgate.net/publication/46450302_Financial_Convergence_in_the_New_ EU_Member_States

Mulder, P., de Groot, H. L. F., \& Kurniawan, H. (2019). Are poor provinces catching-up the rich provinces in Indonesia? Regional Science Policy and Practice, 11(1), 89-108. https://oi.org/10.1111/rsp3.12160

OECD. (2015). Pension funds in figures. Retrieved from https://www.oecd.org/finance/Pension-funds-pre-data-2015.pdf

Phillips, P. C., \& Sul, D. (2007, November). Transition modeling and econometric convergence tests. Econometrica, 75(6), 17711855. https://doi.org/10.1111/j.1468-0262.2007.00811.x

Pisarenko, Zh. V., Kuznetsova, N. P., \& Chernova, G. V. (2017). Comparison of pension reforms in growing giants countries: case of China and Russia International conference "New challenges of economic and business development". University of Latvia, Riga. Retrieved from https://www.bvef.lu.lv/fileadmin/user_upload/lu_portal/projekti/evf_conf2017/Abstracts.pdf

Statistics Times. (2018, April). International monetary fund world economic outlook. Retrieved from https://statisticstimes.com/economy/projected-world-gdp-ranking.php

System of National Accounts. (2008). Retrieved from https://unstats.un.org/unsd/nationalaccount/docs/SNA2008Russian.pdf

Willis Towers Watson. (2018). Retrieved from https://www.willistowerswatson.com/-/media/WTW/Images/Press/2018/01/GlobalPension-Asset-Study-2018-Japan.pdf 